\title{
Spontaneous poisoning by Trema micrantha (Ulmaceae) in goats*
}

\author{
Intoxicação experimental com Trema micrantha (Ulmaceae) em caprinos \\ Sandra Davi Traverso' ${ }^{1}$, Priscila Zlotowski ${ }^{1}$, Marlise Germer' ${ }^{2}$, \\ Cláudio Estevão Farias $\mathrm{Cruz}^{3}$ \& David Driemeier ${ }^{1}$
}

\begin{abstract}
Hepatotoxic plants are important cause of economical losses in farm animals in Brazil. This report concerns an outbreak of acute hepatic toxicosis, in which seven goats died after consumption of green leaves from a felled Trema micrantha tree. Two of these animals were necropsied and several tissues were processed for histological examination. Main histological finding was observed in the liver that showed centrilobular to massive necrosis consistent with an acute hepatic toxicosis. The overall picture was similar to those described in experimentally induced T. micrantha poisoning of goats. No additional known hepatotoxic plant was found in the paddock where the goats had been kept.
\end{abstract}

Key words: spontaneous poisoning, Trema micrantha, goats.

\section{RESUMO}

Plantas hepatotóxicas são importantes causas de prejuízos em herbívoros no Brasil. Este trabalho relata uma hepatotoxicose aguda, ocorrida em 7 caprinos que morreram após a ingestão de folhas verdes de uma árvore de Trema micrantha que foi derrubada. Dois desses animais foram necropsiados e tecidos foram processados para exame histológico. O principal achado histológico foi observado no fígado, consistindo de necrose centrolobular a massiva, compatível com necrose hepática de origem tóxica. Todas as lesões observadas foram similares às descritas nas intoxicações experimentais por Trema micrantha em caprinos. Nenhuma outra planta hepatotóxica conhecida foi encontrada no local onde os caprinos permaneciam.

Descritores: Intoxicação experimental, Trema micrantha, caprinos. 


\section{INTRODUCTION}

Trema micrantha (Figure 1) is a native perennial plant of the Brazil [8]. The genus Trema includes many species of fast growing trees, which are not tolerant to shadow [16]. In Brazil, T. micrantha has been used as a pioneer in reforest systems, especially for the recovery of burned or degraded soils [2,11]. When dosed to mice and rats, the extracts of this plant have showed analgesic and anti-inflammatory activities [1]. Additionally, its leaves have been used in folk medicine as a treatment for skin diseases, syphilis and rheumatism [8].

Death due to T. micrantha poisoning has been induced in two goats three days after the consumption of $30 \mathrm{~g} / \mathrm{Kg}$ of green leaves from the plant [13]. Macroscopically, the liver from these goats were friable and showed an enhanced lobular pattern. The main histological lesion was hepatic necrosis, which ranged from centrilobular to massive and was associated with hemorrhage. Additional histological findings included neuronal degenerative changes. Experimental T. micrantha poisoning associated with an acute hepatic intoxication has also been reported in rabbits [14]. Very similar diseases associated with the consumption of Trema tomentosa have been described in camel [15], cattle, goat, sheep [10], horse [7] and deer [9].

\section{CASE REPORT}

In a small flock of goats located in the Southern Brazil, seven out of fourth-two animals developed progressive apathy which not responded to supportive and symptomatic treatment. Fourth-eight hours after the beginning of the symptoms, all of the seven affected animals had dyed. Two of them were necropsied and several tissues were collected and processed for diagnostic purposes. The animals were managed in a grazing paddock planted with elephantgrass (Pennisetum purpureum). A Trema micrantha tree which was in the paddock area had recently felled and the farmer com-

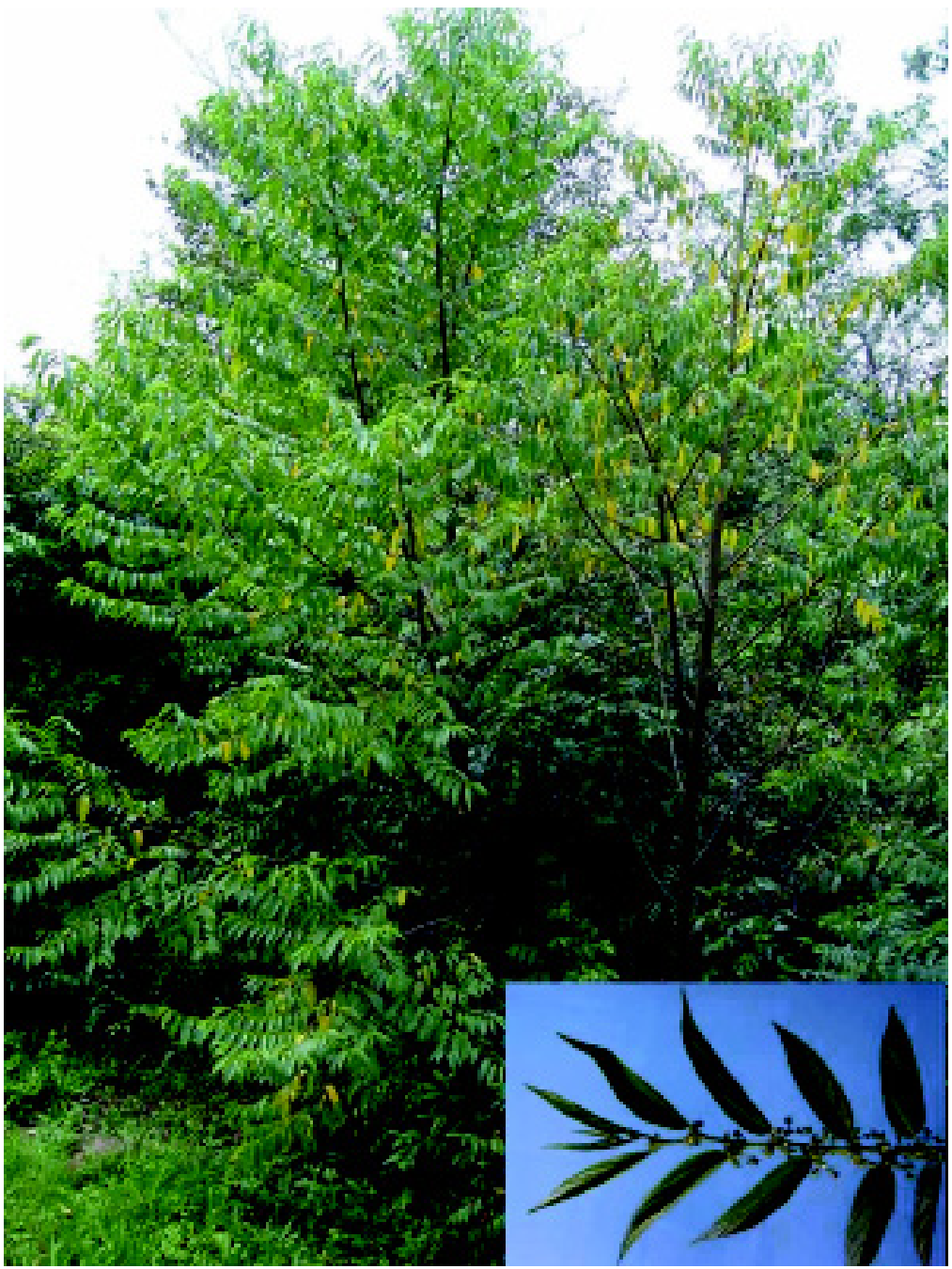

Figure 1. Median sized Trema micrantha tree. Note the branch in detail. October, 2004.

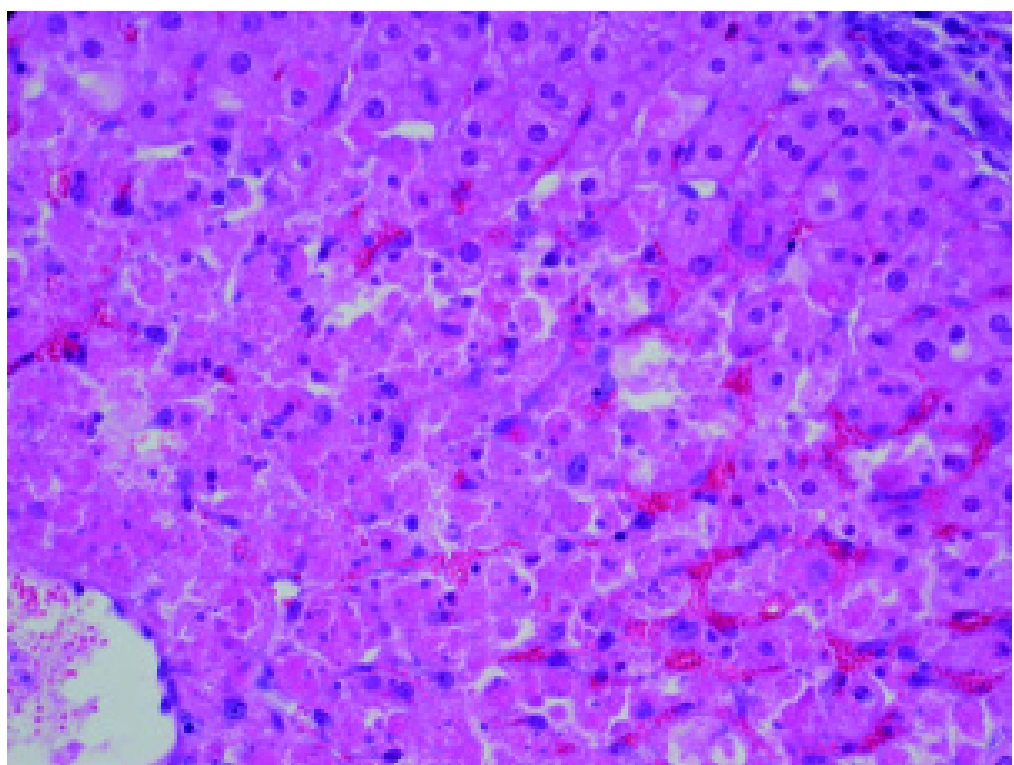

Figure 2. Spontaneous Trema micrantha poisoning. Goat. Liver, centrilobular necrosis and degeneration associated with hepatocyte vacuolization in the portal zones and congestion. HE Obj. 25. 
mented that some goats had been eating its leaves. Additional plant with known hepatotoxic capabilities was not detected in this farm. Enhanced lobular hepatic pattern was observed during macroscopic analysis. Hepatocellular necrosis ranging from centrilobular to diffuse and intense centrilobular hemorrhages and hepatocyte vacuolization in the portal zones from areas of centrilobular necrosis (Figure 2) were observed in the histology.

\section{DISCUSSION}

Hepatic lesions observed here were typical of acute hepatic insufficiency. Hepatocellular necrosis observed in these two necropsied goats was similar to that described in experimentally Trema micrantha poisoned goats [13] and rabbits [14]. As it had previously been observed, T. micrantha may possess good palatability because rabbits, goats have all voluntarily ingested its leaves $[13,14]$. Additional evidence for this hypothesis has been noticed in the present outbreak. High rate con- sumption of a similar plant has been observed during shortage periods of forage [10], however, felled branches or trees by pruning or wind action are important risk factors in T. micrantha poisoning. Before these cases there was no occurrence of sudden death in this flock. There are a number of hepatotoxic plants in southern Brazil that may cause acute hepatotoxicity including Xanthium cavanillesii [4], Cestrum intermedium [6], C. corymbosum var. hirsutum [5], C. parqui [12] and Dodonea viscosa [3] that should be considered in the differential diagnosis of Trema micrantha poisoning. Our diagnosis was based on the possibility of access for the consumption by animals of felled T. micrantha, the observation by farmer of the goats eating the plant, the absence of additional hepatotoxic plants and the similarity between the hepatic histological lesions observed here and those previously described in T. micrantha poisoning $[13,14]$. This report highlights the risk of spontaneous poisoning in livestock that may gain access to pruned branches or felled trees of T. micrantha.

\section{REFERENCES}

1 Barbera R., Trovato A., Rapisarda A. \& Ragusa S. 1992. Analgesic and anti-inflammatory activity in acute and chronic conditions of Trema guineense (Schum. Et Thonn.) Ficalho and Trema micrantha Blume extracts in rodents. Phytotherapy Research. 6: 146-148.

2 Castellani E.D. \& Aguiar I.B. 1998. Preliminary conditions for germination of Trema micrantha (L.) Blume seeds. Revista Brasileira de Engenharia Agrícola e Ambiental. 2: 80-83.

3 Colodel E.M., Traverso S.D., Seitz A.L., Correa A.M.R., Oliveira F.N., Driemeier D. \& Gava A. 2003. Spontaneous poisoning by Dodonea viscosa (Sapindaceae) in Cattle. Veterinary and Human Toxicology. 45: 147-148.

4 Driemeier D., Irigoyen L.F., Loretti A.P., Colodel E.M. \& Barros C.S.L. 1999. Intoxicação espontânea pelos frutos de Xanthium cavanillesii (Asteraceae) em bovinos no Rio Grande do Sul. Pesquisa Veterinária Brasileira. 19: 12-18.

5 Gava A., Stolf L., Pilati C., Neves D.S. \& Viganó L. 1991. Intoxicação por Cestrum corymbosum var. hirsutum (Solanaceae) em bovinos no Estado de Santa Catarina. Pesquisa Veterinária Brasileira. 11: 71-74.

6 Gava A., Stolf L., Varaschin M.S., Neves D.S., Tigre A.P. \& Lesmann F. 1996. Intoxicação por Cestrum intermedium (Solanaceae) em bovinos. Pesquisa Veterinária Brasileira. 16: 117-120

7 Hill B.D., Wills L.D. \& Dowling R.M. 1985. Suspected poisoning of horses by Trema aspera (poison peach). Australian Veterinary Journal. 62: 107-108.

8 Lorenzi H. 2000. Plantas Daninhas do Brasil: terrestres, aquáticas, parasitas e tóxicas. Nova Odessa: Plantarum, 623p.

9 McKenzie R.A., Green P.E., ThorntonA.M., Chung Y.S., MacKenzieA.R., Cybinski D.H. \& St. George T.D. 1985. Diseases of deer in South eastern Queensland. Australian Veterinary Journal. 62: 424.

10 Mulhearn C.R. 1942. Poison peach (Trema aspera): a plant poisonous to stock. Australian Veterinary Journal. 18: 68-72.

11 Nowotny K. \& Nowotny M.P. 1993. Agrossilvicultura baseada na dinâmica e na biodiversidade da Mata Atlântica. In: Jesus E.L, Von der Weid J.M., Grzybowski L.M.C. \& Almeida S.G. (Eds). Alternativas - Cadernos de Agroecologia. Rio de Janeiro: AS-PTA, pp.11-20.

12 Riet-Correa F., Schild A.L. \& Méndez M.C. 1986. Intoxicação por Cestrum parqui (Solanaceae) em bovinos no Rio Grande do Sul. Pesquisa Veterinária Brasileira. 6: 111-115.

13 Traverso S.D., Correa A.M. Pescador C.A., Colodel E.M., Cruz C.E.F. \& Driemeier D. 2002. Intoxicação experimental por Trema micrantha (Ulmaceae) em caprinos. Pesquisa Veterinária Brasileira. 22: 141-147.

14 Traverso S.D. \& Driemeier D. 2000. Experimental Trema micrantha (Ulmaceae) poisoning in rabbits. Veterinary and Human Toxicology. 42: 301-302. 
Traverso S.D., Zlotowski P., Germer M., Cruz C.E.F.\& Driemeier D. 2005. Spontaneous poisoning by Trema micrantha (UImaceae) in goats.

Acta Scientiae Veterinariae. 33: 207-210.

15 Trueman K.F. \& Powell M.W. 1991. Suspected poisoning of camels by Trema tomentosa (poison peach). Australian Veterinary Journal. 68: 213-214.

16 Vasquez Y.C. 1998. Trema micrantha (L) Blume (Ulmaceae): a promising neotropical tree for site amelioretion of deforested land. Agroforestry Systems. 40: 97-104. 